\title{
Analysis of functional relationships between the cell quantification variables in the microalgae Chlorella sorokiniana
}

The applications of microalgae are being increasingly explored, as they have a high rate of cell duplication and accumulation of lipids, ranging from $20-50 \%$ of their dry weight, reaching up to $80 \%$ under appropriate conditions. Their cultivation in artificial conditions has also increased, which has made it important to explore different microalga quantification methods and evaluate its growth kinetics. For algal quantification, it appears that both quantification methods by direct counting in a Neubauer chamber (density) and indirect counting methods such as reading in spectrophotometry (optical density) and dry weight (biomass), are importan to validate the results quantification. The objective of this study was to verify the existence of a functional relationship between the variables used to quantify the microalgae Chlorella sorokiniana. For this purpose, linear regression analysis was applied to the variables of cell density, optical density, and dry biomass that were obtained by cultivating the microalgae at different concentrations. Using the equations generated from the regression analysis in Chlorella sorokiniana, it was possible to obtain cell density values between 3 and $3.8 \times 106 \mathrm{~mL}-1$ and dry biomass values between 0.1 and $4.3 \mathrm{mg} . \mathrm{mL}-1$ from the optical density values acquired using spectrophotometry with extreme precision, and this method was found to be highly feasible.

Keywords: Cellular density; Dry weight; Optical density; Microalgae.

\section{Análise das relações funcionais entre as variáveis de quantificação celular na microalga Chlorella sorokiniana}

\begin{abstract}
As aplicações das microalgas vêm sendo cada vez mais exploradas, por ter alta taxa de duplicação celular e acumulo de lipídios, variando de $20-50 \%$ de seu peso seco, alcançando até $80 \%$ em condições apropriadas. Seu cultivo em condições artificiais também tem aumentado, o que torna importante explorar diferentes métodos de quantificação de microalgas e avaliar sua cinética de crescimento. Para a quantificação algal, verifica-se que tanto os métodos de quantificação por contagem direta em câmara de Neubauer (densidade) quanto métodos indiretos de contagem como leitura em espectrofotometria (densidade ótica) e peso seco (biomassa), são importantes para validar os resultados de quantificação. 0 objetivo deste estudo foi verificar a existência de uma relação funcional entre as variáveis utilizadas para quantificar a microalga Chlorella sorokiniana. Para tanto, a análise de regressão linear foi aplicada às variáveis de densidade celular densidade óptica e biomassa seca que foram obtidas com o cultivo da microalga em diferentes concentrações. Usando as equações geradas a partir da análise de regressão em Chlorella sorokiniana, foi possivel obter valores de densidade celular entre 3 e 3,8 $\times 106 \mathrm{~mL}-1$ e valores de biomassa seca entre 0,1 e $4,3 \mathrm{mg}$. $\mathrm{mL}-1$ a partir dos valores de densidade óptica adquiridos por espectrofotometria com extrema precisão, e este método foi considerado altamente viável.
\end{abstract}

Palavras-chave: Densidade celular; Peso seco; Densidade óptica; Microalgas.

\section{Topic: Biotecnologia}

Reviewed anonymously in the process of blind peer.
Received: 02/01/2021

Approved: 27/01/2021
Nathaskia Silva Pereira Nunes (iD)

Universidade Federal da Grande Dourados, Brasil http://lattes.cnpq.br/2406137946626729

http://orcid.org/0000-0002-0433-6412

nathaskia.spn@gmail.com

Igor Gabriel Silva Oliveira (iD

Universidade Federal da Grande Dourados, Brasil

http://lattes.cnpq.br/4847132030679688

http://orcid.org/0000-0002-1810-1788

igorgabrielso@hotmail.com

\section{Mônica Ansilago (iD}

Universidade Federal da Grande Dourados, Brasil

http://lattes.cnpq.br/4714903275774963

http://orcid.org/0000-0002-7866-3619

monica ansilago@hotmail.com
Emerson Machado de Carvalho

Universidade Federal do Sul da Bahia, Brasil

http://lattes.cnpq.br/7341724276580365

http://orcid.org/0000-0002-4865-6784

carvalho.em@gmail.com
Referencing this:

NUNES, N. S. P.; OLIVEIRA, I. G. S.; ANSILAGO, M.; CARVALHO, E. M.. Analysis of functional relationships between the cell quantification variables in the microalgae Chlorella sorokiniana. Revista Ibero Americana de Ciências Ambientais, v.12, n.1, p.453-460, 2021. DOI: http://doi.org/10.6008/CBPC2179-6858.2021.001.0036 


\section{INTRODUCTION}

Standard routines for quantification of microalgal density usually involve cell counting methods using a microscope (ARAGAW et al., 2017). These techniques allow the estimation of the duplication rates, anatomy and cell size, and cytological mutations, among other visual features. However, in addition to the time required for analysis with this method, a considerable loss of precision in samples having low cell densities was observed (CORCINI et al., 2011).

Other methods for quantifying microalgae involve calculation of wet or dry mass and volume. However, these techniques are time-consuming, have procedures with several stages of preparation, and also have a high probability of systematic errors (HOSSEINIZAND et al., 2018; RODRIGUES et al., 2011). Nevertheless, calculation of mass or volume is the most commonly used technique for quantitative analysis of microalgae, especially when producing and obtaining biomass.

In contrast, there are methods available that can increase the efficiency and decrease the complexity of processes. Quantification using spectrophotometry, for example, is less time consuming, requires smaller sample amounts for quantification, has a lower error probability, and a simplified procedure (РEIXOTO SOBRINHO et al., 2008). Spectrophotometry, which is a technique based on the degree of light absorbance, allows quick measurement and easy handling of samples, and it has been widely used as an alternative to complex and expensive techniques. Paschoal et al. (2003), for instance, used spectrophotometry as an alternative to high-performance liquid chromatography. Brito et al. (2013) adopted the same method to monitor the quality of residual water in situ.

In experiments that seek to quantify cellular metabolites, such as those conducted by Barbarino et al. (2005), Marxen et al. (2007), and Leite et al. (2016), the spectrophotometric technique has been widely used. As for experiments that aim to analyze the growth kinetics of microalgae, the use of density by cell counting method seems to predominate.

In a previous study, Valer et al. (1998) presented equations that allowed us to estimate the algal concentrations of Chlamydomonas reinhardtii, Scenedesmus communis, Cryptomonas phaseolus, and Selenastrum rinoi from the spectrophotometric absorbance data for cell densities between $10^{4}$ and $10^{5}$ cells. $\mathrm{mL}^{-1}$. Rodrigues et al. (2011) had proposed a calibration curve to correlate absorbance values (684 $\mathrm{nm}$ ) and cell density of up to $5.000,000\left(5 \times 10^{6}\right)$ cells $\mathrm{mL}^{-1}$ in Pseudokirchneriella subcapitata.

Despite equations currently available in the literature to quantify the optical density of microalgae, each species has intrinsic characteristics, which makes specific studies necessary, considering their high and low cell densities. Thus, the present study aims to evaluate the relationship between the techniques adopted to estimate cell density, optical density, and dry biomass of the microalgae Chlorella sorokiniana. Therefore, of the different techniques used, it was possible to select one that was the most cost-effective, had a simplified procedure, as well as the potential for adaptation according to the scope of the study and intrinsic needs of the quantification unit. 


\section{METHODOLOGY}

Strains of $C$. sorokiniana (Trebouxiophyceae) used in these assays were acquired from André Tosello Foundation (Ref. 211-32) and grown in vitro in the laboratory of the Biodiversity Research Center (CPBio) at the State University of Mato Grosso do Sul (UEMS).

The strains were grown in a $2.000 \mathrm{~mL}$ Erlenmeyer flask, supplemented with NPK chemical fertilizer (SIPAÚBA-TAVARES and ROCHA 2003; CARVALHO et al., 2012) and vinasse, and maintained in a non-axenic static culture system with constant aeration, and photoperiod and controlled room temperature (12 $\mathrm{h}$

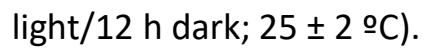

The initial solution was prepared in a proportion between $80 \%$ and $20 \%(\mathrm{v} / \mathrm{v})$ of the culture medium and microalgae inoculum, respectively. For supplementation, $1 \%$ of sugarcane vinasse and $1 \%$ of the N:P:K stock solution were added to make up a total volume of $2.000 \mathrm{~mL}$. The N:P:K stock solution was prepared with 0.70 g. $\mathrm{L}^{-1}$ of N:P:K (20 N-5 P-20 K g.L-1) for each $1.000 \mathrm{~mL}$ of initial solution (SIPAUBA-TAVARES et al., 2003).

From the initial solution, five serial dilutions were prepared with three replicates of each sample, along with appropriate adjustments in the concentrations of $\mathrm{N}: \mathrm{P}: \mathrm{K}$ and vinasse supplements. These microalgae were then grown' instead for 35 days, during which aliquots were collected every five days to perform the respective quantifications as described below.

\section{Quantification using a Neubauer chamber}

An aliquot was removed from each treatment and counted in a Neubauer chamber (hemocytometer) to measure algal density.

\section{Quantification using spectrophotometry}

Through the scanning method, spectral absorption distributions were made in five bands in the 200 to $800 \mathrm{~nm}$ range to verify the light absorption indexes. Subsequently, absorbance values were recorded for each sample at the wavelength at which the absorption peak occurred (686 nm). The equipment was calibrated through blanking with the culture medium used in the production of $C$. sorokiniana.

\section{Biomass quantification}

To determine the dry biomass weight, $2 \mathrm{~mL}$ Eppendorf tubes were initially dried and tared. Next, 2 $\mathrm{mL}$ aliquots were removed from the respective cultures (in duplicate) and transferred to dried tubes. The aliquots were centrifuged in a refrigerated microcentrifuge at 13500 RPM $(18574 \mathrm{~g})$ for $5 \mathrm{~min}$ at $5^{\circ} \mathrm{C}$. Subsequently, the supernatant was discarded and the biomass-containing tubes were dried in an oven at 60 ${ }^{\circ} \mathrm{C}$ until a constant weight was obtained (24-48 h). After drying, the tubes were weighed again. The dry weight was obtained from the difference between the final and initial weights.

$$
D B=\frac{\mathrm{M} 2-\mathrm{M} 1}{\mathrm{~V}}
$$


Where $D B$ is the dry biomass (g. $\left.\mathrm{L}^{-1}\right) ; \mathrm{M} 1$ mass of empty eppendorf (g); $\mathrm{M} 2$ mass of eppendorf with microalgae biomass; $V$ volume used (L).

\section{Data analysis}

Linear regression analysis was used to verify the existence of a functional relationship between the variables used to quantify $C$. sorokiniana microalgae. The equation generated from the analysis represents the amount of variation of the dependent variable that can be explained by the variation of the level(s) of the independent variable(s). To verify the correlation between the variables analyzed, we used Spearman's non-parametric test with a 95\% confidence interval $(p<0.05)$.

\section{RESULTS AND DISCUSSION}

The absorbance values of the diluted $C$. sorokiniana samples indicated that the maximum peak varied between 670 and $690 \mathrm{~nm}$ (Fig. 1). Thus, a wavelength of $686 \mathrm{~nm}$ was selected for the measuring the optical density.

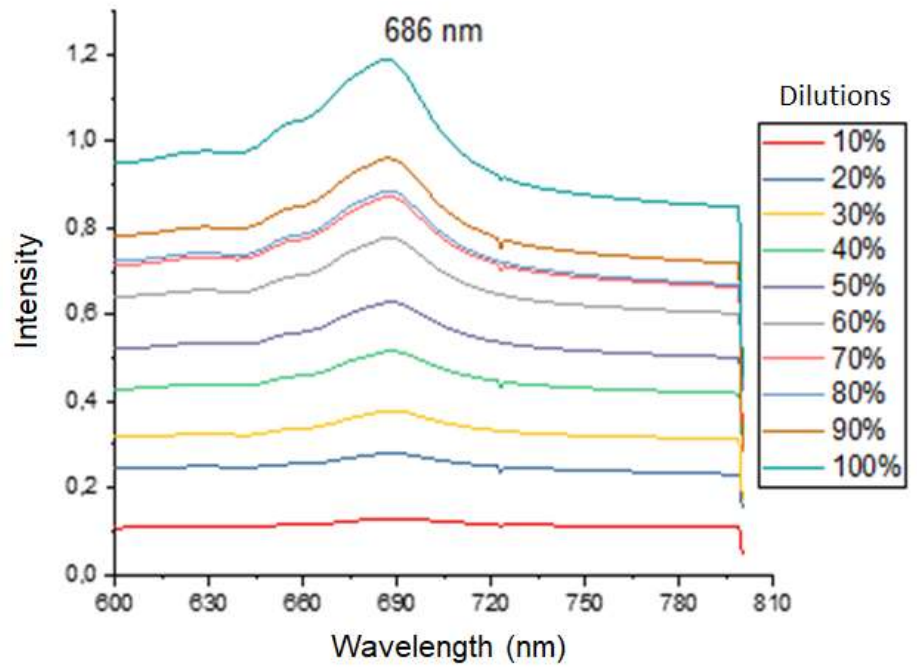

Figure 1: Light absorption pattern of dilutions containing Chlorella sorokiniana traced between 200 and $800 \mathrm{~nm}$.

Subsequently, linear regression (R2) between the variables of optical density, cell density, and dry biomass was analyzed. The results indicated that the best linear regression was between the optical density of the cultivated $C$. sorokiniana and cell density, followed by cell density with dry biomass and optical density with dry biomass (Fig. 2). All crosses were significantly correlated according to the Spearman's test at a confidence level of $95 \%(p<0.05)$. Optical and cell densities showed the highest correlation $(r=0.96 ; p<0.05)$, followed by cell density and dry biomass $(r=0.87 ; p<0.05)$ and optical density and dry biomass $(r=0.75 ; p$ $<0.05)$. Based on these findings, it can be proposed that it is possible to obtain the measurement of algal density, cell density, and biomass of $\boldsymbol{C}$. sorokiniana using only one measurement technique, with greater confidence between optical and cell densities, or vice versa. 

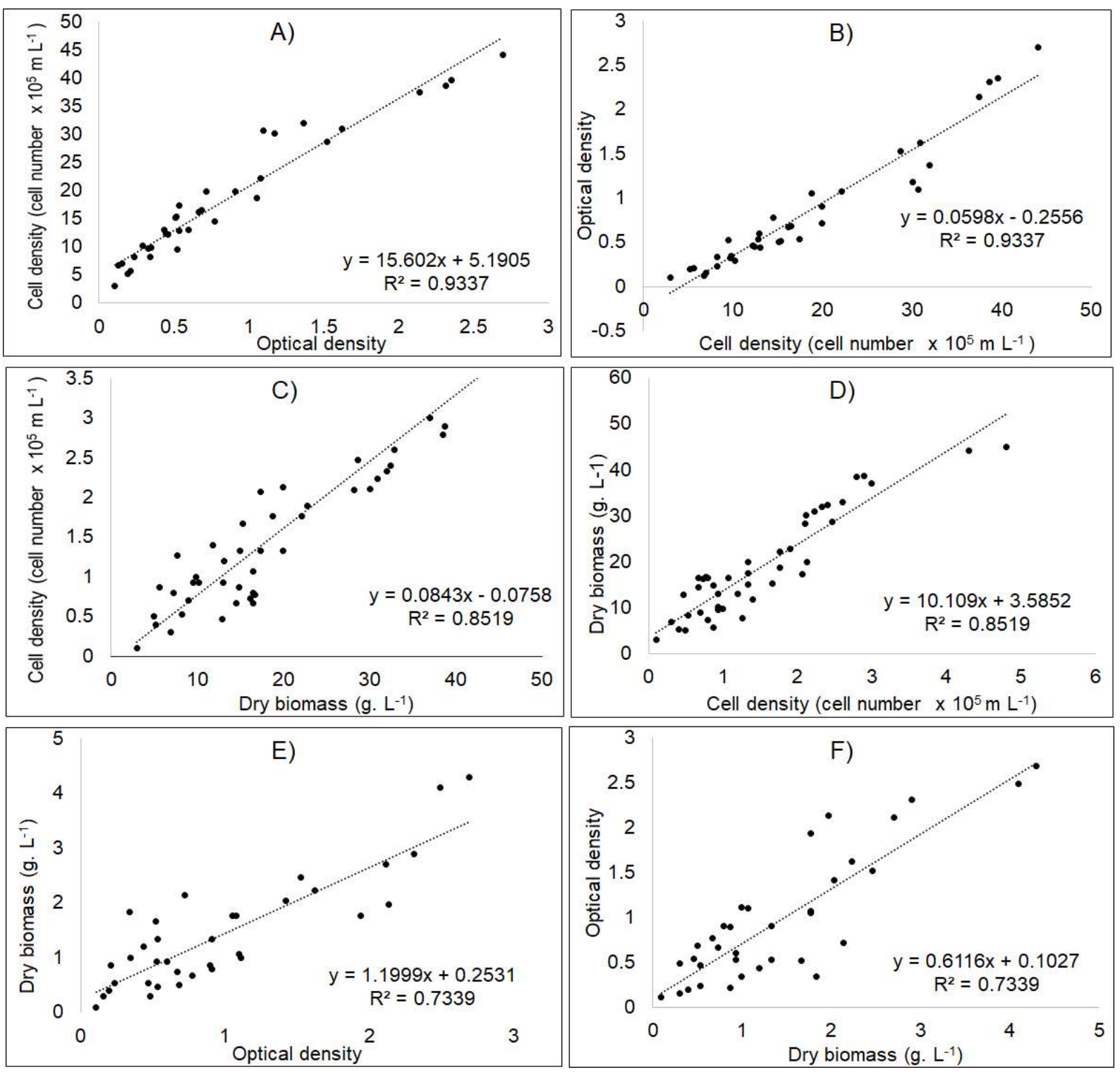

Figure 2: Correlation between variables: A) optical density (absorbance $686 \mathrm{~nm}$ ) and cell density (cell number $\times 10^{5}$ $\mathrm{mL}^{-1}$ ); B) cell and optical densities; C) dry biomass $\left(\mathrm{g} . \mathrm{L}^{-1}\right)$ and cell density; D) cell density and dry biomass; E) optical density and dry biomass; F) dry biomass and optical density.

Linear regression generated the following equations:

Optical density to cell density (cell number $\times 10^{5} \mathrm{~mL}^{-1}$ )

$$
C D=(15.602 . \text { Nod })+5.1905
$$

Where, 15.602 is the regression constant, NoD is the independent variable (optical density), and 5.1905 is the regression coefficient.

\section{Cell density to optical density}

$$
O D=(0.0598 . N c d)+0.2556
$$

Where, 0,0598 is the regression constant, $N_{C D}$ is the independent variable (cell density), and 0.2556 is the regression Dry biomass $\left(g \cdot L^{-1}\right)$ to cell density coefficient $(y=0.0598 x-0.2556)$.

$$
C D=(0.0843 . N d b)+0.0758
$$

Where, 0.0843 is the regression constant, $\mathrm{N}_{\mathrm{BS}}$ is the independent variable (dry biomass), and 0.0758 is the regression Cell density to dry biomass

coefficient $(y=0.0843 x-0.0758)$. 


$$
D B=(10.109 . N c f)+3.582
$$

Where, 10.109 is the regression constant, $\mathrm{NDC}_{\mathrm{D}}$ is the independent variable (cell density), and 3.582 is the regression Optical density to dry biomass coefficient $(y=10.109 x+3.582)$.

$$
D B=(1.999 . \text { Nod })+0.2531
$$

Where, 1.999 is the regression constant, NoD is the independent variable (optical density), and 0.2531 is the regression coefficient $(y=1.999 x+0.2531)$.

\section{Dry biomass to optical density}

$$
O D=(0.6116 \cdot N d b)+0.1027
$$

Where, 0.616 is the regression constant, $\mathrm{N}_{\mathrm{DB}}$ is the independent variable (dry biomass), and 0.1027 is the regression coefficient $(y=0.6116 x+0.1027)$.

When spectrophotometric absorbance is the chosen methodology, it is common to use a wavelength of $750 \mathrm{~nm}$ (EPA, 1994; EATON et al., 1995). However, wavelengths of $687 \mathrm{~nm}$ (VALER et al., 1998$), 684 \mathrm{~nm}$ (RODRIGUES et al. 2011), and $686 \mathrm{~nm}$ (DZIOSA et al., 2016) have also been used in previous studies. All these wavelengths are represented within the wavelength estimated in the present work.

To quantify the algae, techniques such as direct cell counting and quantification of dry biomass and optical density based on absorbance values detected using spectrophotometry can be used. However, some techniques require more time and effort and have a higher probability of error. Among the techniques presented, optical density allows the analysis of a larger number of samples, requires lesser effort, and has a lower probability of error. However, the most widely used methodologies in previous studies include dry biomass and cell density techniques.

Based on these results, it is possible to compare algal production data with other previously reported data. Optical density is a technique that has been previously used for the quantification of microalgal strain growth parameters (CEREIJO et al., 2015; BAUMGARTNER et al., 2013; RODRIGUES et al., 2011). The present study supports that quantification through optical density corresponds to the other techniques used such as cell density or dry biomass. This methodology can be used to simplify the acquisition of data in inoculum preparation or estimate the productivity of microalgal biomass (CEREIJO et al., 2015). However, a spectrophotometer is required in the laboratory for this technique to be viable, which may require an initial investment.

Despite the advantages and disadvantages of each quantification technique, its use is defined by the type of application that is desired for microalgae. Recent studies on in vitro microalgae cultivation show that both methods of quantification, i.e., measuring cell density using a Neubauer chamber or indirect methods such as spectrophotometry (optical density) and dry weight (biomass), are important for validating the results.

Cell density is a low-cost technique, but it has the disadvantage of being exhaustively laborious and can present greater error variability. Depending on environmental factors, such as the type of contaminant used in the assay or even thermal changes, agglutination of microalgal cells may occur, leading to an overestimation or underestimation of cell density. In addition, cell counting requires laboratory staff trained in microscopy and an investment in basic microscopy equipment, such as an efficient binocular microscope 
and Neubauer chamber (hemocytometer).

Alternatively, dry biomass methodology requires considerable time and effort, since the samples must be prepared and completely dried. The microalgae suspended in culture medium must undergo centrifugation to separate the supernatant and then dried in an oven at $60{ }^{\circ} \mathrm{C}$ until a constant weight is obtained (between 24 and $48 \mathrm{~h}$ ). Due to the sequence of processes in this method, errors may occur during the preparation of the microalgal container (Eppendorf tubes, which must be tared and weighed), centrifugation and drying, or even due to interferences in the drying time and sample exchange, thus decreasing the accuracy of the technique. In addition, it requires an investment in a precision analytical balanced centrifuge and a drying oven.

From the results obtained, it was possible to infer that the linear regression between cell and optical densities showed a high correlation, indicating a lower probability of error. Thus, it becomes possible to replace the cell density technique with that of optical density. The conversion of values using a regression equation allows quick and safe quantification of algae from optical densities (VALER et al., 1998). Despite the lower correlation between dry biomass and optical density, the value remains significant and the linear regression equation can be used for quantification by converting optical density values to obtain dry biomass. The process of obtaining dry biomass from microalgae is time-consuming, in addition to being more expensive, as it requires a large amount of energy (HOSSEINIZAND et al., 2018). According to Silva et al. (2007), a correlation index of $r=0.60$ was obtained when correlating the cell density in a hemocytometer with an electronic count from smeared platelets and was considered as a reliable value. The lowest correlation index obtained in this assay was higher than the values reported in the abovementioned study.

\section{CONCLUSIONS}

The equations generated using regression analysis with $C$. sorokiniana samples enabled us to obtain cell density values between 3 and $3.8 \times 10^{6} \mathrm{~mL}^{-1}$ and dry biomass values between 0.1 and $4.3 \mathrm{mg} / \mathrm{mL}$ from the optical density values, which were found to be highly precise in both cases. Values outside this spectrum may present a larger error, which requires further analysis.

Thus, the results indicated that a functional relationship could be obtained for the three algal quantification techniques, namely, cell density, optical density, and dry biomass through linear regression. Therefore, it is possible to quantify microalgae using one chosen technique, which can then be converted to attain other values using the equations generated by linear regression.

Among the methodologies presented, the optical density proved to be the most appropriate owing to its practicality, ease in sample-handling, and rapid results. Based on these results, it is possible to estimate cell density values and dry algal biomass using only optical density values obtained using the spectrophotometric technique.

ACKNOWLEDGMENT: The authors are thankful to Fundação de Apoio ao Desenvolvimento do Ensino, Ciência e Tecnologia do Estado de Mato Grosso do Sul (FUNDECT). 


\section{REFERENCES}

ARAGAW, T. A.; ASMARE, A. M.. Experimental identifications of fresh water microalgae species and investigating the media and $\mathrm{pH}$ effect on the productions of microalgae. Journal of Environmental Treatment Techniques, v.5, n.2, p.124-131, 2017.

BARBARINO, E.; LOURENÇO, S. O.. An evaluation of methods for extraction and quantification of protein from marine macro-and microalgae. Journal of Applied Phycology, v.17, n.5, p.447-460, 2005. DOI: https://doi.org/10.1007/s10811005-1641-4

BAUMGARTNER, T. R. S.; BURAK, J. A. M.; KOGIKOSKI, M. E.; SEBASTIEN, N. Y.. ARROYO PA Avaliação da produtividade da microalga Scenedesmus acuminatus (Lagerheim) Chodat em diferentes meios de cultivo. Revista Brasileira

de Biociências, v.11, n.2, p.250-255, 2013.

BRITO, R. S.; FERREIRA, F.; LOURENÇO, N. D.; PINHEIRO, H. M.; MATOS, J. S.. Espectrofotometria para monitorização da qualidade de água residual em drenagem urbana. Recursos Hídricos, v.34, n.01, p.5-16, 2013. DOI:

https://doi.org/10.5894/rh34n1-1

CARVALHO, E. M.; OTTONELLI, F.; ANSILAGO, M.; GODOY, H. C.; NAKAGAKI, J. M.; RAMIRES, I.. Growth kinetics of the microalga Pseudokirchneriella subcapitata (Korshikov) Hindak (Chlorophyceae) in natural water enriched with NPK fertilizer. Applied Biochemistry and Biotechnology, v.01, n.02, p.14-18, 2012. DOI: https://doi.org/10.5433/2316$\underline{5200.2012 v 1 n 2 p 14}$

CEREIJO, C. R.; SANTANA, H.; SIQUEIRA, F. G.; BRASIL, B. Spectrophotometry as a method for microalgae cultivation analysis. In: LATIN AMERICAN CONGRESS, 4. Anais. Florianópolis: UFSC, 2015.

CORCINI, C. D.; JUNIOR, A. S. V.; PIGOZZO, R.; BONGALHARDO, D. C.; JUNIOR, L. T.. Comparação de diferentes diluentes na mensuração da concentração espermática de suínos em espectrofotômetro Comparison of different diluents to measure swine sperm concentration on the spectrophotometer. Semina: Ciências Agrárias, v.32, n.1, p.1965-1968, 2011. DOI: https://doi.org/10.5433/16790359.2011v32Suplp1965

DZIOSA, K.; MAKOWSKA, M.. Monitoring of Chlorella sp. growth based on the optical density measurement. Problemy Eksploatacji: Maintenance Problems, v.2 p.197-206, 2016.

EATON, A. D.; CLESCERI, L. S.; GREENBERG, A. E.. Standard methods for the examination of water and wastewater.. Washington: American Plublic Health Association, 1995.

EPA. Environmental Protection Agency United States. Shortterm methods for measuring the chronic toxicity of effluents and receiving waters to freshwater organisms. 3 ed. Cincinati: EPA, 1994.
HOSSEINIZAND, H.; SOKHANSANJ, S.; LIM, C. H.. Studying the drying mechanism of microalgae Chlorella vulgaris and the optimum drying temperature to preserve quality characteristics. Drying Technology v.36, n.9, p.1049-1060, 2018. DOI:

https://doi.org/10.1080/07373937.2017.1369986

LEITE, G. B.; PARANJAPE, K.; HALLENBECK, P. C.. Breakfast of champions: fast lipid accumulation by cultures of Chlorella and Scenedesmus induced by xylose. Algal Research v.16, p.338-348, 2016. DOI:

https://doi.org/10.1016/j.algal.2016.03.041

MARXEN, K.; VANSELOW, K. H.; LIPPEMEIER, S.; HINTZE, R.; RUSER, A.; HANSEN, U. P.. Determination of DPPH radical oxidation caused by methanolic extracts of some microalgal species by linear regression analysis of spectrophotometric measurements. Sensors-Basel v.7n.10, p. 2080-2095, 2007. DOI: https://doi.org/10.3390/s7102080

PASCHOAL, L. R.; FERREIRA, W. A.; PRADO, M. R. D.; VILELA, A. P. O.. Aplicação do método da espectrofotometria de derivadas na identificação e doseamento simultâneo de sistemas multicomponentes. Revista Brasileira de Ciências Farmacêuticas, v.39, n.1, p.105-113, 2003. Dol: https://doi.org/10.1590/S1516-93322003000100011

PEIXOTO SOBRINHO, T. J. D. S.; SILVA, C. H. T. P.; NASCIMENTO, J. E.; MONTEIRO, J. M.; ALBUQUERQUE, U. P.; AMORIM, E. L. C.. Validação de metodologia espectrofotométrica para quantificação dos flavonóides de Bauhiniacheilantha (Bongard) Steudel. Revista Brasileira de Ciências Farmacêuticas v.44, n.4, p.683-689, 2008. DOI: https://doi.org/10.1590/S1516-93322008000400015

RODRIGUES, L. H.; ARENZON, A.; RAYA-RODRIGUEZ, M. T.; FONTOURAL, N. F.. Algal density assessed by spectrophotometry: A calibration curve for the unicellular algae Pseudokirchneriella subcapitata. Journal of Environmental Chemistry and Ecotoxicology, v.3, n.8, 2011.

SILVA, P. F. N.; BALARIN, M. R. S.; MARUCHI, H. P.; FLAIBAN, K. K. M. C.; MOROZ, L. R R.. Correlação entre o hemocitômetro e outras técnicas de rotina para a contagem do número de plaquetas em cães atendidos no Hospital Veterinário da Universidade Estadual de Londrina (HV-UEL). Semina: Ciências Agrárias v.28, n.4, 2007.

SIPAUBA-TAVARES, L. H.; ROCHA, O.. Produção de plâncton (fitoplâncton e zooplâncton) para alimentação de organismos aquáticos. 2 ed. São Carlos: RiMa, 2003.

VALER, R. M.; GLOCK, L.. Quantificação de algas clorofíceas de interesse ecotoxicológico através do método espectrofotométrico. Acta Limnologica Brasiliensia, v.11, n.2, p.149-156,1998.

A CBPC - Companhia Brasileira de Produção Científica (CNPJ: 11.221.422/0001-03) detém os direitos materiais desta publicação. Os direitos referem-se à publicação do trabalho em qualquer parte do mundo, incluindo os direitos às renovações, expansões e disseminações da contribuição, bem como outros direitos subsidiários. Todos os trabalhos publicados eletronicamente poderão posteriormente ser publicados em coletâneas impressas sob coordenação da Sustenere Publishing, da Companhia Brasileira de Produção Científica e seus parceiros autorizados. Os (as) autores (as) preservam os direitos autorais, mas não têm permissão para a publicação da contribuição em outro meio, impresso ou digital, em português ou em tradução. 